\title{
Genetic variability and resistance of cultivars of cowpea [Vigna unguiculata (L.) Walp] to cowpea weevil (Callosobruchus maculatus Fabr.)
}

\author{
M.X. Vila Nova ${ }^{1}$, N.G.A. Leite ${ }^{1}$, L.M. Houllou ${ }^{2}$, L.V. Medeiros ${ }^{3}$, \\ A.C. Lira Neto ${ }^{3}$, B.S. Hsie ${ }^{1}$, L.R. Borges-Paluch ${ }^{3}$, B.S. Santos ${ }^{1}$, \\ C.S.F. Araujo ${ }^{1}$, A.A. Rocha ${ }^{1}$ and A.F. Costa $^{3}$ \\ ${ }^{1}$ Universidade Federal de Pernambuco, Cidade Universitária, \\ Recife, PE, Brasil \\ ${ }^{2}$ Centro de Tecnologias Estratégicas do Nordeste, Luiz Freire, \\ Cidade Universitária, Recife, PE, Brasil \\ ${ }^{3}$ Instituto de Pesquisa Agropecuária, Bongi, Recife, PE, Brasil \\ Corresponding author: M.X. Vila Nova \\ E-mail: meiriana_vilanova@yahoo.com.br
}

Genet. Mol. Res. 13 (1): 2323-2332 (2014)

Received July 25, 2013

Accepted January 10, 2014

Published March 31, 2014

DOI http://dx.doi.org/10.4238/2014.March.31.12

\begin{abstract}
The cowpea weevil (Callosobruchus maculatus Fabr.) is the most destructive pest of the cowpea bean; it reduces seed quality. To control this pest, resistance testing combined with genetic analysis using molecular markers has been widely applied in research. Among the markers that show reliable results, the inter-simple sequence repeats (ISSRs) (microsatellites) are noteworthy. This study was performed to evaluate the resistance of 27 cultivars of cowpea bean to cowpea weevil. We tested the resistance related to the genetic variability of these cultivars using ISSR markers. To analyze the resistance of cultivars to weevil, a completely randomized test design with 4 replicates and 27 treatments was adopted. Five pairs of the insect were placed in 30 grains per replicate. Analysis of variance showed that the number of eggs and emerged insects were significantly different in the treatments, and the
\end{abstract}


means were compared by statistical tests. The analysis of the large genetic variability in all cultivars resulted in the formation of different groups. The test of resistance showed that the cultivar Inhuma was the most sensitive to both number of eggs and number of emerged adults, while the TE96-290-12-G and MNC99-537-F4 (BRS Tumucumaque) cultivars were the least sensitive to the number of eggs and the number of emerged insects, respectively.

Key words: Inter simple sequence repeat; Vigna unguiculata; Callosobruchus maculates

\section{INTRODUCTION}

Brazil is the second largest producer of cowpea (Vigna unguiculata), second only to India. It is a staple food for the rural and urban populations in the northeast of Brazil, is considered the most important grain legume, and supplies part of the protein needs of the poorest populations in this region (Oliveira et al., 1984; Araújo and Watt, 1988; Oliveira and Carvalho, 1988; Quin, 1997).

In order to ensure good productivity, it is very important to choose the correct plant variety for a particular environment and production system. Reduced production costs of culture can be optimized by using better technology, such as using upright plant varieties, which facilitate mechanized harvesting, combined with high resistance to pests, such as those that attack the grain (Santos and Vieira, 1971; Santos et al., 1978). It is also desirable that the cultivar in use provides resistance to diseases that are caused by various agents while meeting market and consumer demands (Freire Filho et al., 2000).

Cowpea is significantly affected by viruses, nematodes, fungi, and bacteria; however, one of the most destructive pests, undoubtedly, is the cowpea weevil (Callosobruchus maculatus Fabr.), which reduces the weight and the germinative power of the seed (Dongre et al., 1996). Cowpea weevil infestation, which in some cases starts in pods while still in the field, reduces the weight of the seeds, thereby causing a decline of the nutritional value of the grains (Araújo et al., 1984; Barreto and Quinderé, 2000; Sousa et al., 2008).

In order to increase productivity, there is a need for cultivars with resistance to biotic and abiotic factors, and genetic analysis is an important tool to detect this variability and aspects related to the architecture of the plant (Pessoa et al., 1993; Sanon et al., 2002). An important application of genetics has been molecular markers; inter simple sequence repeat (ISSR) markers stand out because they provide versatile, fast, and reliable results and are effective in diagnosis (Zietkiewicz et al., 1994; Bornet and Branchard, 2001; Reddy et al., 2002; Wolfe et al., 2005; Caixeta et al., 2006). Because the procedure is simple to implement-amplifying specific regions of the genome using small amounts of DNA and samples consisting of several individuals, this technique is advantageous in relation to the cost and time needed to obtain results (Ramos et al., 2006).

Because the susceptibility of the crop to pests, mainly cowpea weevil, is high, little is known about tolerant cultivars, and the most used means of control usually involve high costs for the producer and often include chemical pesticides. It is greatly important to develop resistant cultivars through the discovery of associated molecular markers (Barreto and Quinderé, 
2000). This study aimed to evaluate the resistance of cowpea to the cowpea weevil and relates this to the genetic diversity of different cultivars using ISSR markers.

\section{MATERIAL AND METHODS}

The research was carried out in the Genomics and Entomology laboratories of the Instituto Agronômico de Pernambuco (IPA). The cultivars studied, sent by Empresa Brasileira de Pesquisa Agropecuária (EMBRAPA) Região Norte, were grown in the municipalities of Petrolina, Salgueiro, and Araripina, in the State of Pernambuco.

\section{Analysis of cowpea resistance to cowpea weevil}

To analyze the resistance of cowpea to the cowpea weevil, we adopted a fully randomized experimental design with 4 replicates (A, B, C, and D) for each cultivar and a control group. Samples of 30 grains for each accession of cowpea were placed in 240-mL glass containers, covered with fabric, and kept at room temperature. Five pairs of 1-day-old cowpea weevils $(24 \mathrm{~h}$ ) were placed in each container. After $72 \mathrm{~h}$, the insects were removed, and 6 days later, an egg count was performed. The experiment was observed daily until the $23 \mathrm{rd}$ day, and from the moment that the cowpea weevils began to emerge, they were counted and removed from the sample. Samples from the control group were not infested with cowpea weevils, but they were kept under the same experimental conditions.

\section{Statistical analysis of the resistance test}

With the help of software for statistical analysis, the data that were obtained for the variables of the number of eggs and the number of emerged insects were transformed to log $(\mathrm{x}+1)$, the variance was analyzed by the F-test, and the means were compared by the Tukey and Duncan tests at the $5 \%$ probability level. The results for comparative and statistical analyses of cultivars were organized into tables that were elaborated by the program.

\section{Nuclear DNA extraction}

Nuclear DNA extraction was performed following the protocol that was proposed by Ferreira and Grattapaglia (1998): for each sample, $700 \mu \mathrm{L} 2 \mathrm{X}$ cetyltrimethylammonium bromide (2X CTAB) extraction buffer was added, samples were heated to $60^{\circ} \mathrm{C}$, and 2-mercaptoethanol was added before use to the required amount of buffer at a proportion of $2 \mu \mathrm{L} / \mathrm{mL}$.

The extraction material, around $150 \mathrm{mg}$ foliar tissue from each cultivar, was ground to a fine powder using liquid nitrogen, a crucible, and a pestle. After maceration, samples were collected in Eppendorf tubes containing the $2 \mathrm{X}$ CTAB extraction buffer plus 2-mercaptoethanol. The Eppendorf tubes were incubated in a water bath at $60^{\circ} \mathrm{C}$ for $30 \mathrm{~min}$ and shaken every $10 \mathrm{~min}$ to homogenize the suspension.

In a fume hood, the first extraction was made with $600 \mu \mathrm{L} 24: 1$ chloroform:isoamyl alcohol (CIA). Then, the Eppendorf tubes were shaken for $5 \mathrm{~min}$ to mix the emulsion and centrifuged at a maximum speed of 14,000 rpm for $5 \mathrm{~min}$. After being removed from the centrifuge tubes, the upper (aqueous) phase of each sample was transferred to a new Eppendorf tube. Ex- 
traction was repeated again with $600 \mu \mathrm{L}$ CIA, shaking the samples for $5 \mathrm{~min}$, and centrifuging for $5 \mathrm{~min}$. Subsequently, the aqueous phase of each tube was transferred to a new Eppendorf tube.

Approximately $400 \mu \mathrm{L}$ cold isopropanol, which was equivalent to $2 / 3$ the volume of the aqueous solution, was added to each Eppendorf tube. After the addition of isopropanol, the tubes were centrifuged at $7000 \mathrm{rpm}$ for $5 \mathrm{~min}$ to form a pellet. Following this, the supernatant was discarded, and the pellet washed twice in $1 \mathrm{~mL} \mathrm{70 \%} \mathrm{ethanol} \mathrm{for} 5 \mathrm{~min}$ and again in $1 \mathrm{~mL}$ absolute ethanol for $3 \mathrm{~min}$. After the ethanol was discarded, the pellet was dried in a fume hood for $30 \mathrm{~min}$ and then resuspended in $100 \mu \mathrm{L}$ Tris and ethylenediaminetetraacetic acid $($ EDTA $)+$ RNAse. The tubes were incubated in a water bath for DNA digestion for $120 \mathrm{~min}$ at $37^{\circ} \mathrm{C}$; then, they were removed and stored at $-20^{\circ} \mathrm{C}$.

\section{Nuclear DNA amplification}

The DNA samples were amplified by polymerase chain reaction (PCR) using the primers described in Table 1 and following the protocol described in Table 2. Amplification for GTG5 was performed using the following protocol: a denaturation cycle at $94^{\circ} \mathrm{C}$ for $5 \mathrm{~min}$; 40 cycles of denaturation at $94^{\circ} \mathrm{C}$ for $15 \mathrm{~s}$, annealing at $55^{\circ} \mathrm{C}$ for $45 \mathrm{~s}$, and extension at $72^{\circ} \mathrm{C}$ for $90 \mathrm{~s}$; and a final extension at $72^{\circ} \mathrm{C}$ for $6 \mathrm{~min}$. Amplification with the GACA4 and M13 primers was the same except that the annealing temperature was $45^{\circ} \mathrm{C}$. For all other primers, the standard programming for ISSR markers was used: denaturation at $95^{\circ} \mathrm{C}$ for $15 \mathrm{~min} ; 35$ cycles of denaturation at $94^{\circ} \mathrm{C}$ for $30 \mathrm{~s}$, annealing at $50^{\circ} \mathrm{C}$ for $45 \mathrm{~s}$, and extension at $72^{\circ} \mathrm{C}$ for $2 \mathrm{~min}$; and a final extension at $72^{\circ} \mathrm{C}$ for $7 \mathrm{~min}$.

\begin{tabular}{|c|c|c|c|}
\hline Primer & Sequence & Molecular marker & Reference \\
\hline 01 & ACACACACACA ACACT & ISSR & Universal \\
\hline 842 & GAGAGAGAGAGAGAG & ISSR & Universal \\
\hline 860 & TGTGTGTGTGTGTGT & ISSR & Universal \\
\hline 862 & AGCAGCAGCAGCAGC & ISSR & Universal \\
\hline 868 & GAAGAAGAAGAAGAA & ISSR & Universal \\
\hline 878 & GGATGGATGGATGGA & ISSR & Universal \\
\hline 878 & GGATGGATGGATGGA & ISSR & Universal \\
\hline 886 & СТССТССТССТССТС & ISSR & Universal \\
\hline GTG5 & GTGGTGGTGGTGGTG & ISSR & Lieckfeldt et al. (1993) \\
\hline CGACA4 & GACAGACAGACAGACA & ISSR & Meyer and Mitchell (1995) \\
\hline M13 & GTAAAACGACGGCCA & ISSR & Lieckfeldt et al. (1993) \\
\hline
\end{tabular}

ISSR $=$ Inter-simple sequence repeat.

The ISSR amplification was performed with the primers listed in Table 1 and a $24-\mu \mathrm{L}$ final volume for each sample in a HIBAID thermal cycler according to the protocol described in Table 2. The amplification products were stained with SYBR and separated by electrophoresis on a $1.3 \%$ agarose gel in $0.5 \mathrm{X}$ Tris, borate, EDTA buffer and subjected to 75 volts $/ \mathrm{cm}$ for $150 \mathrm{~min}$. After being withdrawn from the box, the gel was set in an ultraviolet transilluminator and photographed.

\section{Statistical analysis of the amplification products}

The amplifications with the primers $01,842,860,862,868,878,886$, GTG5, GACA4, 
and M13 were analyzed with the numerical taxonomy system of multivariate programsNTSYS-PC 2.1 (Bussab et al., 1990; Rohlf, 1998). The data were transformed into binary variables, in which the number 1 (one) indicates the presence of the band and the number 0 (zero) indicates the absence of the band. A similarity matrix was built using the Jacard similarity coefficient $(\mathrm{J})$, which was calculated according to the formula: $\mathrm{J}=\mathrm{A} / \mathrm{P}-\mathrm{D}$, where $A$ indicates the variables that were present, $P$ indicates the number of variables, and $D$ indicates the variables that were absent. From the similarity matrix, a dendrogram was generated by the unweighted pair group method with arithmetic average clustering method.

\section{RESULTS AND DISCUSSION}

Twenty-seven cowpea cultivars were tested for resistance to cowpea weevil, and the sensitivity level was estimated through the variables of the number of eggs and the number of emerging insects. In Tables 2 and 3 presented below, the variables are compared by the Tukey and Duncan tests at $5 \%$ probability.

In Table 1, according to the average number of eggs for each cultivar, it is possible to separate the data into 3 distinct groups: A, AB, and B. Group A is composed only of the Inhuma cultivar, which showed the highest number of eggs in relation to the others, while group $\mathrm{AB}$ is home to the largest number of cultivars, where there is no significant difference among the means. Group B, however, is composed of the EVX-63-10E, MNC99-510G-8, Patativa, MNC99-537-F4, and TE96-290-12-G cultivars, which exhibited the fewest eggs.

According to Lima et al. (2001), the number of viable eggs in beans can indicate a greater possibility that the plant cultivar will be susceptible to the pest; therefore, there is a

Table 2. Statistical analysis of the egg number variable (Tukey test at 5\% probability level).

\begin{tabular}{|c|c|c|c|c|c|}
\hline Treatments & Repetitions & Means & Standard error & Tukey $(5 \%)$ & Duncan $(5 \%)$ \\
\hline 07-Inhuma & 4 & 227.25 & 33.11 & $\mathrm{a}$ & $\mathrm{a}$ \\
\hline 27-TE97-303G-12-BRS-Pageú & 4 & 153.75 & 48.40 & $a b$ & $a b$ \\
\hline 24-Maravilha & 4 & 152.50 & 20.67 & $a b$ & $a b$ \\
\hline 20-Sempre Verde L. E. Magalhães & 4 & 150.25 & 16.38 & $a b$ & $a b$ \\
\hline 01-IPA 207 & 4 & 137.50 & 17.16 & $a b$ & $a b$ \\
\hline 08-Pingo-de-Ouro 2 & 4 & 134.50 & 37.74 & $a b$ & $a b c$ \\
\hline 25-MNC99-508G-1 & 4 & 126.50 & 71.00 & $a b$ & abcd \\
\hline 21-Rajado & 4 & 117.25 & 45.03 & $a b$ & abcd \\
\hline 15-MNC99-519D-1-1-5 & 4 & 110.75 & 20.63 & $a b$ & abcd \\
\hline 22-Sopinha & 4 & 109.50 & 26.05 & $\mathrm{ab}$ & abcd \\
\hline 09-Pingo-de-Ouro 1-2 & 4 & 107.25 & 46.45 & $a b$ & abcd \\
\hline 03-BRS-Marataoã & 4 & 104.75 & 23.52 & $a b$ & bcd \\
\hline 04-Paulistinha & 4 & 100.50 & 39.25 & $a b$ & bed \\
\hline 26-TE97-304G-4 & 4 & 99.00 & 38.91 & $a b$ & bed \\
\hline 23-Vigna 384 & 4 & 98.75 & 26.03 & $a b$ & bed \\
\hline 11-EVX91-2E-2 & 4 & 92.50 & 19.17 & $a b$ & bed \\
\hline 13-MNC00-553D-8-1-2-3 & 4 & 84.75 & 22.97 & $a b$ & bcde \\
\hline 19-Pretinho & 4 & 83.75 & 12.96 & $a b$ & bcde \\
\hline 16-BRS-Novaera & 4 & 82.75 & 13.93 & $a b$ & bcde \\
\hline 14-BRS-Potengí & 4 & 79.00 & 13.04 & $a b$ & bcde \\
\hline 02-BRS Milênio & 4 & 66.75 & 15.23 & $a b$ & bcde \\
\hline 05-BRS-Paraguaçu & 4 & 55.00 & 13.37 & $a b$ & bcde \\
\hline 10-EVX-63-10E & 4 & 44.25 & 14.92 & $\mathrm{~b}$ & cde \\
\hline 17-MNC99-510G-8 & 4 & 43.25 & 21.66 & $\mathrm{~b}$ & cde \\
\hline 06-Patativa & 4 & 39.25 & 9.94 & $\mathrm{~b}$ & de \\
\hline 12-MNC99-537-F4 & 4 & 30.50 & 17.84 & b & $\mathrm{e}$ \\
\hline 18-TE96-290-12G & 4 & 26.00 & 17.35 & $\mathrm{~b}$ & e \\
\hline
\end{tabular}


greater likelihood that the Inhuma cultivar will be more susceptible to infestation by cowpea weevils than cultivars belonging to group B, which appear to be less susceptible.

Table 3. Statistical analysis of the emerging insects number variable (Tukey test at $5 \%$ probability level).

\begin{tabular}{|c|c|c|c|c|c|}
\hline Treatments & Repetitions & Means & Standard error & Tukey $(5 \%)$ & Duncan $(5 \%)$ \\
\hline 07-Inhuma & 4 & 127.50 & 16.18 & a & $\mathrm{a}$ \\
\hline 27-TE97-303G-12-BRS-Pageú & 4 & 101.50 & 27.64 & $\mathrm{ab}$ & $\mathrm{ab}$ \\
\hline 08-Pingo-de-Ouro 2 & 4 & 94.75 & 30.86 & $\mathrm{ab}$ & $a b c$ \\
\hline 09-Pingo-de-Ouro 1-2 & 4 & 80.00 & 41.12 & $a b c$ & abcd \\
\hline 20-Sempre Verde L. E. Magalhães & 4 & 69.25 & 1.03 & $a b c$ & abcde \\
\hline 25-MNC99-508G-1 & 4 & 68.25 & 27.35 & $a b c$ & abcde \\
\hline 04-Paulistinha & 4 & 68.00 & 28.53 & $a b c$ & abcde \\
\hline 24-Maravilha & 4 & 60.25 & 3.68 & $a b c$ & abcde \\
\hline 26-TE 97-304G-4 & 4 & 57.50 & 22.71 & $a b c$ & bcde \\
\hline 03-BRS-Marataoã & 4 & 55.50 & 12.84 & $a b c$ & bcde \\
\hline 01-IPA 207 & 4 & 51.25 & 5.04 & $a b c$ & bcde \\
\hline 23-Vigna 384 & 4 & 46.75 & 11.80 & $a b c$ & bcdef \\
\hline 22-Sopinha & 4 & 44.75 & 11.79 & $a b c$ & bcdef \\
\hline 16-BRS-Novaera & 4 & 42.75 & 10.83 & $a b c$ & bcdef \\
\hline 15-MNC99-519D-1-1-5 & 4 & 41.75 & 7.33 & $a b c$ & bcdef \\
\hline 11-EVX91-2E-2 & 4 & 37.25 & 8.20 & $a b c$ & bcdef \\
\hline 02-BRS Milênio & 4 & 37.00 & 11.21 & $a b c$ & bcdef \\
\hline 14-BRS-Potengí & 4 & 30.25 & 8.94 & $a b c$ & cdef \\
\hline 21-Rajado & 4 & 30.00 & 9.28 & $a b c$ & def \\
\hline 17-MNC99-510G-8 & 4 & 26.75 & 16.94 & $a b c$ & def \\
\hline 19-Pretinho & 4 & 26.25 & 3.42 & $a b c$ & def \\
\hline 10-EVX-63-10E & 4 & 26.00 & 9.59 & $\mathrm{bc}$ & def \\
\hline 13-MNC00-553D-8-1-2-3 & 4 & 25.50 & 3.52 & $\mathrm{bc}$ & def \\
\hline 18-TE96-290-12G & 4 & 24.75 & 16.99 & bc & def \\
\hline 06-Patativa & 4 & 23.25 & 7.56 & $\mathrm{bc}$ & def \\
\hline 05-BRS-Paraguaçu & 4 & 23.00 & 5.76 & bc & ef \\
\hline 12-MNC99-537-F4 & 4 & 16.25 & 10.15 & $\mathrm{c}$ & $\mathrm{f}$ \\
\hline
\end{tabular}

In Table 2, according to the number of emerging insects for each cultivar, it is also possible to divide the data into 3 distinct groups: $\mathrm{A}, \mathrm{AB}$, and $\mathrm{B}$. Again, Group $\mathrm{A}$ is composed only of the Inhuma cultivar, which is considered to be the most susceptible because it had a greater number of emerging insects than the others; this indicated that there is a direct correlation between the number of eggs and the number of emerging insects in this cultivar. Group $\mathrm{AB}$ comprises the largest number of cultivars in which there was no significant difference among the means. However, the cultivars EVX-63-10E, MNC99-510G-8, and TE96-290-12-G, which previously were scored as less susceptible to oviposition and belonged to group $B$, now became part of group $A B$, which indicates that there is no direct correlation between the number of eggs and the number of emerging insects in these cultivars. Group B is composed only of the Patativa and MNC99-537-F4 cultivars, which are considered less susceptible because they presented fewer emerging insects.

According to Barreto and Quinderé (2000), the number of eggs and the number of emerging insects were significantly and positively correlated with each other. However, according to Lara (1997), the genotypes with the most oviposition are not always the most susceptible; there may be other factors that prevent insect larval development. In this way, a genotype with heavy oviposition can still prove to be resistant.

\section{Genetic variability}

The same cultivars that were tested for resistance to C. maculatus were also analyzed 
for genetic variability using ISSR molecular markers. Among the 10 markers that were used for the analysis, $7(01,842,860,862,868,878$, and 886) were selected for the study according to the profiles they presented on $1.3 \%$ agarose gels. To test the primers, Sempre Verde cultivar was used, which was the same cultivar that was used as the control group in the endurance test.

In total, the 10 primers that were selected $(01,842,860,862,868,878,886$, GTG5, GACA4, and M13) produced 1337 bands. The dendrogram that was obtained by cluster analysis with the 10 primers showed great genetic variability, enough to discriminate all the cowpea cultivars at the molecular level. According to Falcão et al. (2004), when ISSR molecular markers were used in different organisms, significant differences can be observed in the amplification, which can be used to detect the polymorphism among the organisms studied and assess the differences among these organisms. Sharma et al. (2008) identified gender differences of the species Simmondsia chinensis (jojoba) before flowering by using ISSR markers. This identification was valuable because researchers did not have any other means to detect this difference. In order to obtain this result, they used 8 cultivars of jojoba and 42 ISSR primers. In this study, it was not possible to relate the most molecularly variable groups with the most resistant or susceptible cultivars to cowpea weevils; we determined that there was great genetic variability and distance among the most susceptible cultivars.

Abadio (2007) reviewed the grouping of ISSR data in Phaeoisariopsis griseola and produced a dendrogram that separated the isolates into 28 genotypes, detecting variability more efficiently than other molecular methods, including enterobacterial repetitive intergenetic consensus PCR and box sequences-polymerase chain reaction (BOX-PCR). The high level of polymorphism that was detected showed that the ISSR-PCR technique was suitable for discriminating the genotype of $P$. griseola. In our study, it was possible to observe a high level of intra-specific variation among the cultivars, whether resistant or sensitive to the cowpea weevil (75\%; Tables 1 and 2), in the dendrogram that was generated by ISSR-PCR. The Inhuma cultivar was extremely susceptible to cowpea weevil attack, but in the dendrogram, it presented similarity of around $75 \%$ to the third group, which included Sopinha cultivar that features $42 \%$ resistance to cowpea weevil, and it was in a group far from Inhuma according to the resistance statistical data. Nevertheless, the genetic variability, as shown in this study, is not directly related to the resistance of the cultivars tested.

Dwivedi et al. (2001) assessed the genetic diversity of 26 accessions of peanut with 8 polymorphic primers. We used 11 primers that resulted in the formation of 3 genotypic groups, indicating that a small number of primers can generate information about the genetic variability of the 27 cultivars.

All cultivars that were evaluated presented a similarity of about $65 \%$, which indicates significant polymorphism among the cultivars. The first group included the cultivars MNC99508G-1, MNC99-510G-8, TE97-4, and TE97-304G-12-BRS-Pageú, which shared about 90\% similarity, and the TE96-290-12G cultivar, which shared about $80 \%$ similarity with the other cultivars in this group. The second group consists of 11 cultivars, including 10 that were about $80 \%$ similar, while the cultivar MNC99-537-F4 presented approximately $75 \%$ similarity in relation to the others. In the third group, there were also 11 cultivars, including 10 that were about $80 \%$ similar, while Pretinho cultivar showed about $75 \%$ similarity with the rest of this group. It is believed that the high similarity among the cultivars resulted from the process of domestication, which contributed to a loss of genetic variability that was most pronounced by the establishment of easily detected features, such as the color and size of the seed, plant size, and type of pod (Vaillancourt et al., 1993). 


\section{Relationship between genetic variability and resistance to the cowpea weevil}

When we examined the correlation between the genetic variability of cultivars and the level of susceptibility to cowpea weevil, we observed that Inhuma, which was considered to be the most susceptible based on the number of eggs and emerging insects, was about $85 \%$ similar to Sempre Verde, L.E. Magalhães, and Sopinha cultivars (Figure 1). However, these cultivars were significantly distant from Inhuma cultivar in terms of the level of susceptibility because they were part of the $\mathrm{AB}$ group for the two variables, indicating that there was no correlation between polymorphism and the level of susceptibility for these cultivars.

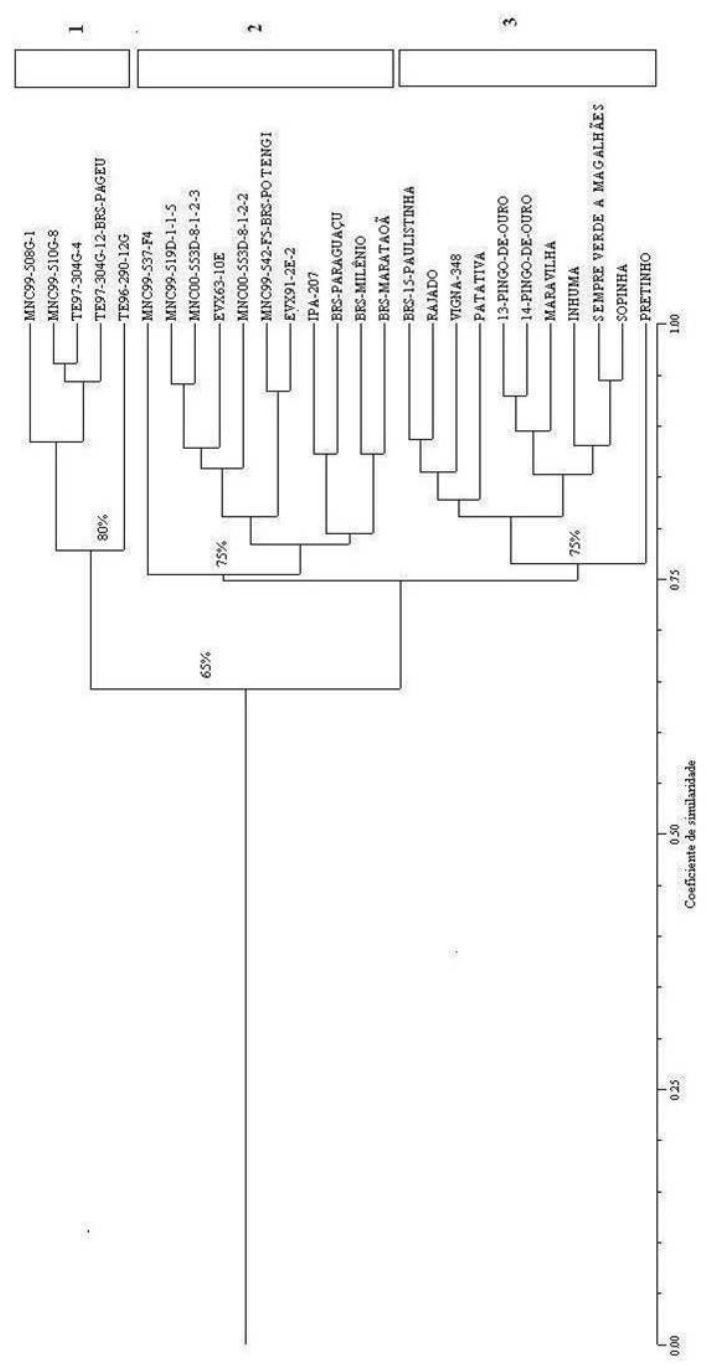

Figure 1. Dendrogram constructed by the unweighted pair group method with arithmetic average grouping method, using Jacard's coefficient of similarity and based on the molecular profiles (inter-simple sequence repeat markers) obtained from 27 cultivars of cowpea. 
As for the TE96-290-12G cultivar, which was less susceptible to the number of eggs, it was approximately $80 \%$ similar to MNC99-508G-1, MNC99-510G-8, TE97-304G, and TE97-304G-12-BRS-Pageú. However, despite this great similarity, the cultivars distanced themselves significantly in the level of susceptibility to both variables, except MNC99-510G-8 cultivar, which approached TE96-290-12G for the variable of number of eggs, as shown with the Tukey test at $5 \%$, where no significant difference was found between them.

In terms of the number of emerging insects, the cultivar MNC99-537-F4 was considered to be the least susceptible. Despite revealing about $75 \%$ similarity with the cultivars belonging to its group, there was no closeness among them in terms of the level of susceptibility according to both number of emerging insects and number of eggs. It is worthwhile to compare our study with that of Tymon and Pell (2005). In their study, 30 isolates of the entomopathogenic fungus $P$. neoaphidis from different geographic origins were analyzed using the ISSR technique; they demonstrated a high level of intra-specific variation among the isolates, but they did not identify groups that were related to the geographic origin.

According to the results that we obtained, it can be affirmed that a positive correlation is not mandatory between the levels of polymorphism and susceptibility. We observed that cultivars with great similarity in terms of genetic variability (Figure 1) distanced themselves in terms of their susceptibility to the variables that were studied.

\section{REFERENCES}

Abadio AKR (2007). Análise da Diversidade Genética de Isolados de Phaeoisariopsis Griseola por Meio de Marcadores Molecular. Master's thesis, Departamento de Microbiologia, Instituto de Biotecnologia Aplicada à Agropecuária, UFV, Viçosa.

Araújo JPP and Watt EE (1988). O Caupi no Brasil. 1st edn. EITA/EMBRAPA, Brasília.

Araújo JPP, Rios GP, Watt EE and Neves BP (1984). A Cultura do Caupi, Vigna unguiculata (L.) Walp.: Descrição e Recomendações Técnicas de Cultivo. EMBRAPA-CNPAF, Goiânia.

Barreto PD and Quinderé MAW (2000). Resistência de genótipos de caupi ao caruncho. Pesq. Agropec. Bras. 35: $361-368$.

Bornet B and Branchard M (2001). Nonanchored inter simple sequence repeat (ISSR) markers: reproducible and specific tools for genome fingerprinting. Plant Mol. Biol. Rep. 19: 209-215.

Bussab WO, Miazaki ES and Andrade DF (1990). Introdução à Análise de Agrupamentos. $9^{\circ}$ Simpósio Nacional de Probabilidade e Estatística, Associação Brasileira de Estatística, São Paulo, 105.

Caixeta ET, Oliveira ACB, Brito GG and Sakiyama NS (2006). Tipos de Marcadores Moleculares. In: Marcadores Moleculares (Borém A and Caixeta ET, eds.). UFV, Viçosa, 9-78.

Dongre TK, Pawar SE, Thakare RG and Harwalkar MR (1996). Identification of resistant sources to cowpea weevil (Callosobruchus maculatus (F.)) in Vigna sp. and inheritance of their resistance in black gram (Vigna mungo var. mungo). J. Stored Prod. Res. 32: 201-204.

Dwivedi SL, Gurtu S, Chandra S and Yuejin W (2001). Assessment of genetic diversity among selected groundnut germplasm. I: RAPD analysis. Plant Breed. 120: 345-359.

Falcão C, Pappas M, Lourenço RT and Batista ARS (2004). Desenvolvimento e Mapeamento de Microssatélites Derivados de EST em Eucaliptos. Circular Técnica 32, Brasília.

Ferreira ME and Grattapaglia D (1998). Introdução ao Uso de Marcadores Moleculares em Análise Genética. 3rd edn. EMBRAPA-CENARGEN, Brasília, 200.

Freire Filho FR, Ribeiro VQ and Santos AA (2000). Cultivares de Caupi para a Região Meio-Norte do Brasil. In: A Cultura do Feijão Caupi no Meio-Norte do Brasil Embrapa Meio-Norte, Embrapa Meio-Norte. Circular Técnica, 28, Teresina, 264.

Lara FM (1997). Resistance of wild and near isogenic bean lines with arcelin variants to Zabrotes subfasciatus (Boheman). I- winter crop. An. Soc. Entomol. Bras. 26: 551-559.

Lieckfeldt E, Meyer W and Borner T (1993). Rapid identification and differentiation of yeasts by DNA and PCR fingerprinting. J. Basic Microbiol. 33: 413-425.

Lima MPL, Oliveira JV, Barros R and Torres JB (2001). Estabilidade da resistência de genótipos de caupi a Callosobruchus maculatus (Fabr.) em gerações sucessivas. Sci. Agric. 59: 275-280. 
Meyer W and Mitchell TG (1995). Polymerase chain reaction fingerprinting in fungi using single primers specific to minisatellites and simple repetitive DNA sequences: strain variation in Cryptococcus neoformans. Electrophoresis 16: $1648-1656$.

Oliveira AP and Carvalho AM (1988). A Cultura do Caupi nas Condições de Clima e de Solo dos Trópicos Úmidos de Semi-Árido do Brasil. In: O Caupi no Brasil (Araújo JPP and Watt EE, eds.). EMBRAPA-CNPAF, Brasília, 65-69.

Oliveira FJ, Santos JHR, Alves JF and Paiva JB (1984). Perdas de peso em sementes de cultivares de caupi, atacadas pelo caruncho. Pesq. Agropec. Bras. 19: 47-52.

Pessoa GP, Barros R and Oliveira JV (1993). Avaliação da resistência de caupi (Vigna unguiculata (L.) Walp.) a Callosobruchus maculatus (Fabr.) em confinamento em laboratório. An. Soc. Entomol. Bras. 22: 259-266.

Quin FM (1997). Introduction. In: Advances in Cowpea Research (Sing BB, Mohan Raj DR, Dashiel KE and Jackai LEN, eds.). IITA-JIRCAS, Ibadan, 9-15.

Ramos NP, Brunelli KR, Camargo LEA and Filho JM (2006). Sensibilidade dos microssatélites para determinar a pureza varietal em sementes de milho. Rev. Bras. Sementes 28: 99-105.

Reddy MP, Sarla N and Siddiq EA (2002). Inter simple sequence repeat (ISSR) polymorphism and its application in plant breeding. Euphytica 128: 9-17.

Rohlf FJ (1998). On applications of geometric morphometrics to studies of ontogeny and phylogeny. Syst. Biol. 47: 147-158.

Sanon A, Garba M, Auger J and Huignard J (2002). Analysis of the insecticidal activity of methylisothiocyanate on Callosobruchus maculatus (F.) (Coleoptera: Bruchidae) and its parasitoid Dinarmus basalis (Rondani) (Hymenoptera: Pteromalidae). J. Stored Prod. Res. 38: 129-138.

Santos JHR and Vieira FV (1971). Ataque do Callosobruchus maculatus (F.) a Vigna sinensis Endl. I. Influência sobre o poder germinativo de semente da cv. Seridó. Ciênc. Agron. 1: 71-74.

Santos JHR, Alves JF and Oliveira FJ (1978). Perda de peso em sementes de Vigna sinensis (L.) Savi, decorrente do ataque de Callosobruchus maculatus (F., 1775) (Col., Bruchidae): primeira aproximação. Ciênc. Agron. 8: 51-56.

Sharma K, Agrawal V, Gupta S and Kumar R (2008). ISSR marker-assisted selection of male and female plants in a promising dioecious crop: jojoba (Simmondsia chinensis). Plant Biotechnol. Rep. 2: 239-243.

Sousa AH, Brito JE and Maia PHS (2008). Ataque do Callosobruchus maculatus ao feijão caupi comercializado em Teresina-PI. Expressão 39: 77-80.

Tymon AM and Pell JK (2005). ISSR, ERIC and RAPD techniques to detect genetic diversity in the aphid pathogen Pandora neoaphidis. Mycol. Res. 109: 285-293.

Vaillancourt RE, Weeden NF and Barnard J (1993). Isozyme diversity in the cowpea species complex. Crop Sci. 33 : 606-613.

Wolfe AD, Randle CP, Liu L and Steiner KE (2005). Phylogeny and biogeography of Orobanchaceae. Folia Geobot. 40: 115-134.

Zietkiewicz E, Rafalski A and Labuda D (1994). Genome fingerprinting by simple sequence repeat (SSR)-anchored polymerase chain reaction amplification. Genomics 20: 176-183. 